\title{
Analysis of Amateur Soccer Players' Leadership Levels in Terms of Their Positions
}

\author{
Egemen Ermiş \\ Correspondence: Egemen Ermiş, Ondokuz Mayıs University, Yaşar Doğu Faculty of Sport Sciences, Samsun, Turkey
}

Received: March 11, 2019

doi:10.11114/jets.v7i6.4125

\author{
Accepted: April 15, $2019 \quad$ Online Published: April 22, 2019 \\ URL: https://doi.org/10.11114/jets.v7i6.4125
}

\begin{abstract}
The purpose of this study is to examine the leadership characteristics of amateur soccer players in terms of positions and some variables. 300 amateur soccer players playing in different clubs in the districts and the city centre of the province of Samsun were included in the study. A personal information form was given to subjects to find out their positions and some variables and Leadership Scale for Sport which was developed by Chelladurai and Saleh (1980) and which included 40 items and five subscales (training and instruction, democratic behaviour, social support, positive feedback and autocratic behaviour) was used to find out leadership levels. SPSS 22.0 program was used in the statistical analysis of the study. When the results of the study were examined, statistically significant difference was found only in positive feedback subscale when the subjects' leadership levels were compared according to age groups and education levels $(p<0.05)$, while no significance was found in other subscales ( $p>0.05)$. When leadership levels were compared in terms of the total period of time they played soccer, their positions, the number of clubs they played for and the state of being the captain, no statistical significance was found in all of the subscales ( $p>0.05)$. As a conclusion, it can be seen that leadership levels of soccer players did not differ according to positions, the state of being the captain, the total period of time they played soccer and the number of clubs they played for, while positive feedback was found to develop positively only as age and the state of education increased.
\end{abstract}

Keywords leadership, soccer player, position, soccer

\section{Introduction}

Leadership has been assigned great importance in sport by athletes, coaches, and spectators (Chelladurai \& Riemer, 1998). Investigation of leadership behaviour and the effects of leadership in sport is very important in terms of understanding the performance of sport teams as an organization. Gardner et al. (1996) described the importance of studying the relationship of leader behavior, cohesion and performance relationship. It has been indicated that there are many factors for a successful performance in sport and that the factors influencing performance are grouped in two as internal sources and external sources (Ödemiş \& Karagün, 2016, p.5201) It has been emphasized that in addition to internal factors such as age, gender, intelligence and psychological state, which are independent of external effects and which are partly innate; there are also external states such as temperature, climate, equipment, spectators, social environment, friendship, economic state and coach, which result from external factors and which indirectly influence performance (Bayraktar \& Kurtoğlu, 2009, p.16). Soccer is one of the sport branches greatly influenced by these internal and external factors.

Performance in soccer does not only include physical, technical and tactical skills, but also psychological skills such as imagination, showing peak performance under stress, commitment, coping with stress, competition anxiety, determining a target, attention, concentration and leadership (Beswick, 2001). The concept of leadership, which is one of these psychological effects, is defined as the behavioural process influencing individuals and the group for predetermined purposes (Barrow, 1977, p.231). A leader is a person who coordinates the group, plans the work, has a say in the group and speaks for the group; a leader's primary mission is to make sure that duties are successfully fulfilled in the group (Kaya, 1996). Various studies have shown that leadership levels and some psychological and performance parameters influence ability of perception, making positive assessment, integrating with the team, imagining, coping with stress and managing competition anxiety (Horne \& Carron, 1985, p.137; Riemer \& Chelladurai, 1995, p.276; Summers \& Russel, 1991,p.30; Maby, 1997, p.5902; Konter, 2005, p.17; Garland \& Barry, 1988, p.237; Gordon, 1998, p.36; Prapavessis, 1991; Pargman, 1998, p.296; Doğan et al., 2018, p.403; Kabadayı et al., 2017; Yilmaz et al., 2017; Cavusoglu et al., 2017, p.150; Bostanc1 et al., 2017, p.205; Bayram et al., 2017; Keskin et al., 2016, p.1; Bostanc1, 2014, p.1021). In 
addition, Garland and Barry (1988) defined good performance in soccer as time players are in the game and showed that five leadership factors consisting of training and instruction, democratic behaviour, autocratic behaviour, giving positive feedback and providing social support are important in predicting performance. It was found that the factor predicting performance level was autocratic behaviour and that there was a significant difference between autocratic behaviour and lower performance. Robinson and Carron (1982) showed results supporting these results.

So far, majority of research on athlete leadership has mostly been descriptive in nature. Yukelson, Weinberg, Richardson, and Jackson (1983) examined the characteristics of collegiate athletes who were rated high as leaders compared to those rated lower in leadership status. Another topic of interest in athlete leadership has been to examine the playing position of team captains who are the formal leaders of a team. Lee, Cobum, and Partridge (1983) hypothesized that soccer players occupying a central playing position (i.e., center fullback, midfield) were more likely to be designated team captains since they occupied positions requiring high interactions with others. The results of this study indicated that captains were more likely to occupy central playing positions on soccer teams regardless of the level of competition.

The fact that players' positions can necessitate different physical and physiological requirements (Beck, 1991; Robinson \& Carron, 1982, p.364; Bansgbo, 1994; Konter, 1997) can also necessitate different psychological skill requirements. Goldberg (1998) stated that physical, technical, tactical and mental requirements can differ from sport to sport and even in terms of positions played in a sport. Although studies have been conducted about positions and psychological skills in sport psychology so far, the number of studies is still limited and the results found are far from definite results. It is thought that the biggest reason for this is differences in branch, socio-economic differences and other psychological and physical characteristics. For instance, while Konter (1996) did not find a difference between positions of players in soccer and their pre-game state anxiety, Leonard (1987) found significant differences about positions in university basketball.

Based on all this information, the purpose of this study is to compare the leadership levels of amateur soccer players in terms of their positions and some parameters. The results of the study showed whether leadership levels, which have been researched in a limited number of studies and which are thought to have a significant influence on performance in terms of sport psychology, caused differences between positions in soccer, which is one of the most popular sports of our day.

\section{Method}

\subsection{Study Design}

300 male soccer players who were actively playing in the amateur sports clubs in the districts and city centre of Samsun province were included in the study. Leadership Scale for Sport-Preferred leader behaviour form developed by Chelladurai and Saleh (1980) was used in the study to find out the leadership characteristics of the players. The participants filled in informed consent form and they were told that it was important to read the questions and fill in the questionnaire form carefully in terms of the validity and reliability of the study. The positions and demographic information of the participants were determined with the personal information form prepared by the researcher.

\subsection{Leadership Scale for Sport}

Leadership Scale for Sport which was developed by Chelladurai and Saleh (1980) and which included 40 items can be applied on athletes in every branch and every level. Leadership Scale for Sport consists of a total of 5 subscales. These are training and instruction, democratic behaviour, social support, positive feedback and autocratic behaviour. According to the results of analysis performed to test the reliability values of the scale used in the study, Cronbach Alpha coefficients were found as 0.73 (training and instruction), 0.82 (democratic behaviour), 0.76 (autocratic behaviour), 0.69 (social support) and 0.70 (positive feedback). In addition, total internal consistency coefficient of the scale was found as 0.79 . These results are within acceptable limits that can be accepted as "good".

\subsection{Data Analysis}

SPSS version 22.0 was used for statistical analyses. Normality assumption was examined with Shapiro-Wilk test. In case of normal distribution, groups of two were analyzed with independent $t$ test, while groups of more than two were analyzed with ANOVA test. When the groups were not normally distributed, groups of two were analyzed with Mann Whitney $U$ test, while groups of more than two were analyzed with Kruskall Wallis test. p value of less than 0.05 was considered as statistically significant. 


\section{Results}

Table 1. Descriptive Information of the Participants

\begin{tabular}{|c|c|c|c|}
\hline & & $\mathrm{N}$ & $\%$ \\
\hline \multirow[t]{2}{*}{ Level of Education } & High school & 92 & $30.7 \%$ \\
\hline & Undergraduate & 208 & $69.3 \%$ \\
\hline \multirow[t]{3}{*}{ Age group } & 20 years and younger & 94 & $31.3 \%$ \\
\hline & Between 21 and 25 years & 162 & $54.0 \%$ \\
\hline & $\begin{array}{l}26 \text { years and younger and } \\
\text { older }\end{array}$ & 44 & $14.7 \%$ \\
\hline \multirow[t]{4}{*}{ Total years of playing soccer } & Between 1 and 5 years & 40 & $13.3 \%$ \\
\hline & Between 6 and 10 years & 164 & $54.7 \%$ \\
\hline & Between 11 and 15 years & 84 & $28.0 \%$ \\
\hline & 16 years and more & 12 & $4.0 \%$ \\
\hline \multirow[t]{7}{*}{ Positions of players } & Defense & 26 & $8.7 \%$ \\
\hline & Forward & 74 & $24.7 \%$ \\
\hline & Goal keeper & 20 & $6.7 \%$ \\
\hline & Midfielder & 94 & $31.3 \%$ \\
\hline & Right-left winger & 20 & $6.7 \%$ \\
\hline & Right-left back & 34 & $11.3 \%$ \\
\hline & Stopper & 32 & $10.7 \%$ \\
\hline \multirow[t]{5}{*}{ Number of clubs } & 1 & 44 & $14.7 \%$ \\
\hline & 2 & 64 & $21.3 \%$ \\
\hline & 3 & 60 & $20.0 \%$ \\
\hline & 4 & 40 & $13.3 \%$ \\
\hline & 5 or more & 92 & $30.7 \%$ \\
\hline \multirow{2}{*}{$\begin{array}{l}\text { Have you ever been a captain } \\
\text { during the time you played } \\
\text { soccer? }\end{array}$} & Yes & 180 & $60.0 \%$ \\
\hline & No & 120 & $40.0 \%$ \\
\hline
\end{tabular}

Table 2. Comparison of Leadership Characteristics based on the players' level of education

\begin{tabular}{|c|c|c|c|c|c|c|}
\hline & & & $\mathrm{N}$ & Average & Std. Deviation & $\mathrm{p}$ \\
\hline \multirow[t]{2}{*}{ Training and instruction } & \multirow{2}{*}{$\begin{array}{ll}\begin{array}{l}\text { Level } \\
\text { education }\end{array} & \text { of } \\
\end{array}$} & High School & 92 & 53.43 & \pm 3.46 & \multirow{2}{*}{0.505} \\
\hline & & Undergraduate & 208 & 53.60 & \pm 4.24 & \\
\hline \multirow[t]{2}{*}{ Democratic behaviour } & \multirow{2}{*}{$\begin{array}{ll}\text { Level of } \\
\text { education }\end{array}$} & High School & 92 & 36.22 & \pm 3.13 & \multirow{2}{*}{0.891} \\
\hline & & Undergraduate & 208 & 36.28 & \pm 3.84 & \\
\hline \multirow[t]{2}{*}{ Social support } & \multirow{2}{*}{$\begin{array}{ll}\begin{array}{l}\text { Level } \\
\text { education }\end{array} & \text { of } \\
\end{array}$} & High School & 92 & 33.17 & \pm 2.84 & \multirow{2}{*}{0.815} \\
\hline & & Undergraduate & 208 & 33.65 & \pm 4.68 & \\
\hline \multirow[t]{2}{*}{ Positive feedback } & \multirow{2}{*}{$\begin{array}{ll}\text { Level of } \\
\text { education }\end{array}$} & High School & 92 & 18.20 & \pm 2.57 & \multirow{2}{*}{$0.039 *$} \\
\hline & & Undergraduate & 208 & 19.23 & \pm 2.63 & \\
\hline \multirow[t]{2}{*}{ Autocratic behaviour } & \multirow{2}{*}{$\begin{array}{ll}\text { Level of } \\
\text { education }\end{array}$} & High School & 92 & 19.22 & \pm 2.20 & \multirow{2}{*}{0.785} \\
\hline & & Undergraduate & 208 & 19.34 & \pm 2.50 & \\
\hline
\end{tabular}

$* \mathrm{p}<0.05$

When soccer players' leadership characteristics were compared in terms of their levels of education, significance was found only in positive feedback subscale $(\mathrm{p}=0.039$. $\mathrm{p}<0.05)$, while no significance was found in other subscales $(\mathrm{p}>0.05)$ (Table 2). 
Table 3. Comparison of soccer players' leadership characteristics in terms of age groups

\begin{tabular}{|c|c|c|c|c|c|c|}
\hline & & & $\mathrm{N}$ & Average & Std. Deviation & $\mathrm{p}$ \\
\hline \multirow[t]{3}{*}{ Training and instruction } & \multirow[t]{3}{*}{ Age group } & 20 and younger & 94 & 54.02 & \pm 3.78 & \multirow{3}{*}{0.747} \\
\hline & & Between 21-25 & 162 & 53.14 & \pm 4.27 & \\
\hline & & 26 and older & 44 & 54.05 & \pm 3.42 & \\
\hline \multirow[t]{3}{*}{ Democratic behaviour } & \multirow[t]{3}{*}{ Age group } & 20 and younger & 94 & 36.43 & \pm 3.13 & \multirow{3}{*}{0.599} \\
\hline & & Between 21-25 & 162 & 36.36 & \pm 4.01 & \\
\hline & & 26 and older & 44 & 35.55 & \pm 3.13 & \\
\hline \multirow{3}{*}{ Social support } & \multirow[t]{3}{*}{ Age group } & 20 and younger & 94 & 33.68 & \pm 2.37 & \multirow{3}{*}{0.379} \\
\hline & & Between 21-25 & 162 & 33.48 & \pm 5.18 & \\
\hline & & 26 and older & 44 & 33.23 & \pm 3.29 & \\
\hline \multirow[t]{3}{*}{ Positive feedback } & \multirow[t]{3}{*}{ Age group } & 20 and younger & 94 & 18.19 & \pm 2.57 & \multirow{3}{*}{$0.047^{*}$} \\
\hline & & Between 21-25 & 162 & 19.07 & \pm 2.57 & \\
\hline & & 26 and older & 44 & 19.86 & \pm 2.80 & \\
\hline \multirow[t]{3}{*}{ Autocratic behaviour } & \multirow[t]{3}{*}{ Age group } & 20 and younger & 94 & 19.26 & \pm 2.26 & \multirow{3}{*}{0.608} \\
\hline & & Between 21-25 & 162 & 19.22 & \pm 2.53 & \\
\hline & & 26 and older & 44 & 19.68 & \pm 2.30 & \\
\hline
\end{tabular}

$* \mathrm{p}<0.05$

When soccer players' leadership characteristics were compared in terms of age group, significance was found only in positive feedback subscale ( $\mathrm{p}=0.047$. $\mathrm{p}<0.05)$, while no significance was found in other subscales $(\mathrm{p}>0.05)($ Table 3$)$.

Table 4. Comparison of soccer players' leadership characteristics in terms of total years of playing soccer

\begin{tabular}{|c|c|c|c|c|c|c|}
\hline & & & $\mathrm{N}$ & Average & Std. Deviation & $\mathrm{p}$ \\
\hline \multirow[t]{4}{*}{ Training and instruction } & \multirow[t]{4}{*}{ Total years of playing soccer } & Between 1 and 5 years & 40 & 52.25 & \pm 4.09 & \multirow{4}{*}{0.172} \\
\hline & & Between 6 and 10 years & 164 & 53.50 & \pm 3.80 & \\
\hline & & Between 11 and 15 years & 84 & 54.31 & \pm 4.43 & \\
\hline & & 16 years and more & 12 & 53.17 & \pm 2.79 & \\
\hline \multirow[t]{4}{*}{ Democratic behaviour } & \multirow[t]{4}{*}{ Total years of playing soccer } & Between 1 and 5 years & 40 & 36.20 & \pm 3.38 & \multirow{4}{*}{0.215} \\
\hline & & Between 6 and 10 years & 164 & 35.98 & \pm 2.73 & \\
\hline & & Between 11 and 15 years & 84 & 37.19 & \pm 4.93 & \\
\hline & & 16 years and more & 12 & 33.83 & \pm 3.49 & \\
\hline \multirow[t]{4}{*}{ Social support } & \multirow[t]{4}{*}{ Total years of playing soccer } & Between 1 and 5 years & 40 & 34.47 & \pm 7.46 & \multirow{4}{*}{0.792} \\
\hline & & Between 6 and 10 years & 164 & 33.21 & \pm 2.29 & \\
\hline & & Between 11 and 15 years & 84 & 33.52 & \pm 5.26 & \\
\hline & & 16 years and more & 12 & 34.33 & \pm 1.97 & \\
\hline \multirow[t]{4}{*}{ Positive feedback } & \multirow[t]{4}{*}{ Total years of playing soccer } & Between 1 and 5 years & 40 & 18.25 & \pm 3.11 & \multirow{4}{*}{0.431} \\
\hline & & Between 6 and 10 years & 164 & 18.78 & \pm 2.64 & \\
\hline & & Between 11 and 15 years & 84 & 19.50 & \pm 2.33 & \\
\hline & & 16 years and more & 12 & 18.83 & \pm 3.06 & \\
\hline \multirow[t]{4}{*}{ Autocratic behaviour } & \multirow[t]{4}{*}{ Total years of playing soccer } & Between 1 and 5 years & 40 & 19.55 & \pm 2.42 & \multirow{4}{*}{0.589} \\
\hline & & Between 6 and 10 years & 164 & 19.37 & \pm 2.24 & \\
\hline & & Between 11 and 15 years & 84 & 19.24 & \pm 2.74 & \\
\hline & & 16 years and more & 12 & 18.00 & \pm 2.28 & \\
\hline
\end{tabular}

When soccer players' leadership characteristics were compared in terms of total years of playing soccer, no statistical significance was found in all subscales $(\mathrm{p}>0.05)$ (Table 4). 
Table 5. Comparison of soccer players' leadership characteristics in terms of their positions

\begin{tabular}{|c|c|c|c|c|c|c|}
\hline & & & $\mathrm{N}$ & Average & $\begin{array}{c}\text { Std. } \\
\text { Deviation }\end{array}$ & $\mathrm{p}$ \\
\hline \multirow[t]{7}{*}{ Training and instruction } & \multirow[t]{7}{*}{ Positions of players } & Defense & 26 & 53.00 & \pm 3.42 & \multirow{7}{*}{0.863} \\
\hline & & Forward & 74 & 53.43 & \pm 3.78 & \\
\hline & & Goal keeper & 20 & 53.80 & \pm 5.73 & \\
\hline & & Midfielder & 94 & 54.17 & \pm 3.82 & \\
\hline & & Right-left winger & 20 & 52.90 & \pm 2.28 & \\
\hline & & Right-left back & 34 & 52.94 & \pm 5.75 & \\
\hline & & Stopper & 32 & 53.31 & \pm 3.26 & \\
\hline \multirow[t]{7}{*}{ Democratic behaviour } & \multirow[t]{7}{*}{ Positions of players } & Defense & 26 & 35.23 & \pm 3.90 & \multirow{7}{*}{0.290} \\
\hline & & Forward & 74 & 35.78 & \pm 2.89 & \\
\hline & & Goal keeper & 20 & 36.00 & \pm 2.79 & \\
\hline & & Midfielder & 94 & 36.28 & \pm 2.76 & \\
\hline & & Right-left winger & 20 & 35.10 & \pm 2.38 & \\
\hline & & Right-left back & 34 & 36.24 & \pm 3.31 & \\
\hline & & Stopper & 32 & 39.06 & \pm 6.67 & \\
\hline \multirow[t]{7}{*}{ Social support } & \multirow[t]{7}{*}{ Positions of players } & Defense & 26 & 32.23 & \pm 4.38 & \multirow{7}{*}{0.825} \\
\hline & & Forward & 74 & 33.17 & \pm 2.35 & \\
\hline & & Goal keeper & 20 & 36.00 & \pm 8.89 & \\
\hline & & Midfielder & 94 & 33.15 & \pm 2.32 & \\
\hline & & Right-left winger & 20 & 33.30 & \pm 1.70 & \\
\hline & & Right-left back & 34 & 35.65 & \pm 7.29 & \\
\hline & & Stopper & 32 & 32.63 & \pm 3.28 & \\
\hline \multirow[t]{7}{*}{ Positive feedback } & \multirow[t]{7}{*}{ Positions of players } & Defense & 26 & 17.92 & \pm 3.43 & \multirow{7}{*}{0.461} \\
\hline & & Forward & 74 & 18.68 & \pm 2.40 & \\
\hline & & Goal keeper & 20 & 20.10 & \pm 2.23 & \\
\hline & & Midfielder & 94 & 19.32 & \pm 2.64 & \\
\hline & & Right-left winger & 20 & 18.90 & \pm 3.35 & \\
\hline & & Right-left back & 34 & 18.24 & \pm 2.59 & \\
\hline & & Stopper & 32 & 19.06 & \pm 2.26 & \\
\hline \multirow[t]{7}{*}{ Autocratic behaviour } & \multirow[t]{7}{*}{ Positions of players } & Defense & 26 & 18.85 & \pm 2.27 & \multirow{7}{*}{0.701} \\
\hline & & Forward & 74 & 19.49 & \pm 2.59 & \\
\hline & & Goal keeper & 20 & 18.80 & \pm 1.55 & \\
\hline & & Midfielder & 94 & 19.13 & \pm 2.48 & \\
\hline & & Right-left winger & 20 & 19.90 & \pm 2.33 & \\
\hline & & Right-left back & 34 & 19.29 & \pm 2.64 & \\
\hline & & Stopper & 32 & 19.69 & \pm 2.33 & \\
\hline
\end{tabular}

When soccer players' leadership characteristics were compared in terms of their positions, no statistical significance was found in all subscales ( $\mathrm{p}>0.05)$ (Table 5). 
Table 6. Comparison of soccer players' leadership characteristics in terms of the number of clubs they played in

\begin{tabular}{|c|c|c|c|c|c|c|}
\hline & & & $\mathrm{N}$ & Average & $\begin{array}{c}\text { Std. } \\
\text { Deviation }\end{array}$ & $\mathrm{p}$ \\
\hline \multirow[t]{5}{*}{ Training and instruction } & \multirow[t]{5}{*}{ Number of clubs } & 1 & 44 & 52.32 & 4.60 & \multirow{5}{*}{0.646} \\
\hline & & 2 & 64 & 54.16 & 4.21 & \\
\hline & & 3 & 60 & 53.57 & 4.39 & \\
\hline & & 4 & 40 & 53.75 & 3.52 & \\
\hline & & 5 or more & 92 & 53.61 & 3.51 & \\
\hline \multirow[t]{5}{*}{ Democratic behaviour } & \multirow[t]{5}{*}{ Number of clubs } & 1 & 44 & 35.86 & 2.71 & \multirow{5}{*}{0.287} \\
\hline & & 2 & 64 & 36.12 & 3.34 & \\
\hline & & 3 & 60 & 35.30 & 2.81 & \\
\hline & & 4 & 40 & 37.05 & 2.98 & \\
\hline & & 5 or more & 92 & 36.83 & 4.72 & \\
\hline \multirow[t]{5}{*}{ Social support } & \multirow[t]{5}{*}{ Number of clubs } & 1 & 44 & 32.95 & 2.65 & \multirow{5}{*}{0.622} \\
\hline & & 2 & 64 & 34.47 & 5.60 & \\
\hline & & 3 & 60 & 32.69 & 3.04 & \\
\hline & & 4 & 40 & 33.70 & 1.92 & \\
\hline & & 5 or more & 92 & 33.52 & 4.95 & \\
\hline \multirow[t]{5}{*}{ Positive feedback } & \multirow[t]{5}{*}{ Number of clubs } & 1 & 44 & 18.36 & 3.08 & \multirow{5}{*}{0.107} \\
\hline & & 2 & 64 & 18.66 & 3.12 & \\
\hline & & 3 & 60 & 18.50 & 2.24 & \\
\hline & & 4 & 40 & 18.55 & 2.48 & \\
\hline & & 5 or more & 92 & 19.78 & 2.26 & \\
\hline \multirow[t]{5}{*}{ Autocratic behaviour } & \multirow[t]{5}{*}{ Number of clubs } & 1 & 44 & 19.32 & 2.42 & \multirow{5}{*}{0.723} \\
\hline & & 2 & 64 & 19.47 & 2.65 & \\
\hline & & 3 & 60 & 19.33 & 2.19 & \\
\hline & & 4 & 40 & 18.65 & 2.32 & \\
\hline & & 5 or more & 92 & 19.43 & 2.46 & \\
\hline
\end{tabular}

When soccer players' leadership characteristics were compared in terms of the number of clubs they played in, no statistical significance was found in all subscales $(\mathrm{p}>0.05)$ (Table 6).

Table 7. Comparison of soccer players' leadership characteristics in terms of their state of being captain

\begin{tabular}{|c|c|c|c|c|c|c|}
\hline & & & $\mathrm{N}$ & Average & $\begin{array}{c}\text { Std. } \\
\text { Deviation } \\
\end{array}$ & $\mathrm{p}$ \\
\hline \multirow[t]{2}{*}{ Training and Instruction } & \multirow{2}{*}{$\begin{array}{l}\text { Have you ever been a captain during the time you } \\
\text { played soccer? }\end{array}$} & Yes & 180 & 53.87 & 3.66 & \multirow[b]{2}{*}{0.476} \\
\hline & & No & 120 & 53.07 & 4.46 & \\
\hline \multirow[t]{2}{*}{ Democratic behaviour } & \multirow{2}{*}{$\begin{array}{l}\text { Have you ever been a captain during the time you } \\
\text { played soccer? }\end{array}$} & Yes & 180 & 36.34 & 3.98 & \multirow[b]{2}{*}{0.813} \\
\hline & & No & 120 & 36.13 & 3.04 & \\
\hline \multirow[t]{2}{*}{ Social support } & \multirow{2}{*}{$\begin{array}{l}\text { Have you ever been a captain during the time you } \\
\text { played soccer? }\end{array}$} & Yes & 180 & 33.21 & 2.85 & \multirow[b]{2}{*}{0.747} \\
\hline & & No & 120 & 33.93 & 5.64 & \\
\hline \multirow[t]{2}{*}{ Positive feedback } & \multirow{2}{*}{$\begin{array}{l}\text { Have you ever been a captain during the time you } \\
\text { played soccer? }\end{array}$} & Yes & 180 & 19.07 & 2.52 & \multirow[b]{2}{*}{0.600} \\
\hline & & No & 120 & 18.68 & 2.83 & \\
\hline \multirow[t]{2}{*}{ Autocratic behaviour } & \multirow{2}{*}{$\begin{array}{l}\text { Have you ever been a captain during the time you } \\
\text { played soccer? }\end{array}$} & Yes & 180 & 19.09 & 2.35 & \multirow[b]{2}{*}{0.162} \\
\hline & & No & 120 & 19.62 & 2.47 & \\
\hline
\end{tabular}

When soccer players' leadership characteristics were compared in terms of the state of being captain, no statistical significance was found in all subscales ( $p>0.05$ ) (Table 7).

\section{Discussion}

When the results of the existing study were examined in general, difference was found only in positive feedback subscale in terms of the variables of age (Table 3) and level of education $(\mathrm{p}<0.05)$. These results show that as age increases, the characteristic of positive feedback also increases and similarly, as the level of education increases, the style of positive feedback develops. However, in terms of the leadership levels of soccer players based on their positions, 
which is the primary purpose of our study, statistical difference was not found in any of the subscales. Similarly, no statistical significance was found in the variables of total years of playing soccer, how many clubs soccer players played in and their state of having been a captain ( $p>0.05)$.

There are a great number of studies conducted in literature examining leadership characteristics according to different branches. However, there are limited numbers of studies on soccer. When some of these are examined, it can be seen that none of the positions had more important or more dominant characteristics when compared with the others. Regardless of position, some players in the team were found to be more dominant in some psychological parameters when compared with others. Konter (1996) examined soccer players' pre-game state anxiety in terms of their positions and did not find a difference. Leonard (1987) on the other hand found significant difference in basketball players in terms of positions. In the Orientation Inventory they applied on 17 different soccer teams and their leaders in English Football League, Cooper and Payne (1972) found that attacking players were significantly more self-orientated than both Staff and Defense, while managers were more task-oriented than attackers and defense. Türksoy's (2006) study which assessed leadership characteristics of soccer players in Super League and First League in terms of their positions did not show any differences for defense, midfield and forward players in terms of democratic, training and instruction and autocratic behaviour subscales, while positive feedback subscale was found to differ significantly for goalkeepers. While training and instruction subscale was found to differ for midfielders in the present study which was conducted on amateur league, in Türksoy's study which was conducted on Super League and First League, positive feedback subscale was found to differ significantly for goalkeepers. It is thought that such a difference occurs from the positions of players and league status. In another study conducted, Chelladurai and Riemer (1980) grouped soccer players in two as offensive and defensive. The results of this study showed that defense players' scores about democratic behaviour subscale differed significantly. It is thought that the difference between this study and our study results from the fact that the study was conducted on only one team, the concept of position was grouped only in two (defense and offense) and there were cultural differences between the countries.

Çakıoğlu (2003) conducted a study on university students playing soccer and reported that the results obtained for all positions showed a significant difference on autocratic behavior characteristics. In Donuk's (2006) study, which analyzed coaches' behaviours on professional soccer players, it was found that coaches in Turkish Professional soccer leagues had an autocratic characteristic according to athletes' perceptions. As can be seen from these results, there are differences between positions and leadership levels. It is thought that these differences can be due to players' state of being professional or amateur, the leagues they play in, socioeconomic levels, lifestyles and a great number of psychological factors. In addition, in terms of some of the characteristics of players who had leadership characteristics, Yukelson et al. (1983) stated that besides skills and experience, internal control was also a good indicator in predicting leadership status. Players who felt more control on their environment were found to have higher scores in leadership scale. Glenn et al. found that players who had high competence perceptions and global self-respect, low external control and high psychological androgyny were assessed as having higher leadership characteristics by their friends. The aforementioned studies addressed personality characteristics about player leadership. In terms of coaches, competence/ability was found to be associated with leadership characteristics. It can be argued that one of the significant concepts associated with success and performance in soccer is being the team captain. In professional soccer, it is a known fact that generally players who have been in the team for a longer time, who show a more regular and stable performance, who have more experience and who show more leadership characteristics become the captain (Konter, 2004). In the present study, no statistical significance was found in leadership levels when the state of being captain was taken into consideration (Table 7). However, Pargman (1998) stated that players who had high success motivation were assigned to leadership position by their coaches with a higher possibility and concluded that this was because coaches considered having a motivation for success as a primary factor for success. Konter (2004) reported that coaches generally expected players with physical ability and skills to be leaders or chose such players as captain and also players determined leadership about their friends with different criteria. According to these results, coaches can expect leadership from players who are not accepted by other players in the team or they can assign such players as the captain. This in turn reveals the question whether the captains in the team are a real leader. That is, coaches generally choose captains who are success oriented and who have skills, experience and professionalism in terms of soccer and this choice sometimes causes them to make players who do not have leadership characteristics to captain teams. The result that there were no significant differences between the state of being captain and leadership levels can be explained with these.

As a conclusion, it can be seen that leadership levels in soccer did not differ according to factors such as position, state of being captain, years of playing soccer and the number of clubs players played in and that only positive feedback states developed significantly as their age and level of education increased. Based on these results and the literature, it is thought that leadership does not only depend on players' experience or positions in their field, but can develop with other psychological and sociological factors and that soccer players' leadership characteristics will stand out more as their age and level of education increase. 


\section{References}

Bangsbo, J. (1994). Fitness training in football. a scientific approach. Copenhagen: HO+Storm. Bagsvaerd.

Barrow, J. C. (1977). The variables of leadership: A review and conceptual framework. Academy of Management Review, 2, 231-251. https://doi.org/10.5465/amr.1977.4409046

Bayraktar, B., \& Kurtoğlu. M. (2009). Sporda Performans. Etkili Faktörler. Değerlendirilmesi ve Arttırılması. Klinik Gelişim, (s.16-24).

Bayram, L., Keskin, D. Ö. Y., Bostanci, Ö., Kabadayi, M., \& Derebaşi, D. G. (2017). Examınıng Aggressıon Levels Of Elite Rugby Athletes In Terms Of Communication Skılls. European Journal of Education Studies.

Beck, M. (1991). Soccer fit. training and health for soccer players. Swindon: The Crowood Press.

Beswick. B. (2001). Focued for soccer. IIIinois: Human Kinetics.

Bostanci, O. (2014). Trait anxiety levels of university students studying at sports departments. Educational Research and Reviews, 9(20), 1021-1024. https://doi.org/10.5897/ERR2014.1875

Bostancı, Ö., Oda, B., Şebin, K., \& Erail, S. (2017). 11-13 Yaş Öğrencilerin Spor Yapma Durumlarına Göre İyimserlik İle Saldırganlık Düzeylerinin İncelenmesi. Beden Eğitimi ve Spor Bilimleri Dergisi, 19(4), 205-217.

Çakığlu, A. (2003). Leadership and satisfaction in soccer: Examination of congruence and players position (Futbolda liderlik ve sporcu tatmini: Tercih edilen ve gerçek liderlik davranışı arasındaki uyum ve sporcu pozisyonuaçısından değerlendirilmesi) Ankara. Orta Doğu Teknik Üniversitesi Sosyal Bilimler Enstitüsü. Yüksek Lisans Tezi.62.

Cavusoglu, G., Yılmaz, A. K., Kabadayı, M., Abac1, S. H., \& Tasmektepligıl, M. Y. (2017). Comparison of narcissism levels of students in the faculty of sports sciences in terms of some demographic variables. Turkish Journal of Sport and Exercise, 19(2), 150-156.

Chelladurai, P., \& Saleh, S. D. (1980). Dimensions of Leader Behavior in Sports: Development a Leadership Scale. Journal of Sport Psychology, 2, 34-45. https://doi.org/10.1123/jsp.2.1.34

Chelladurai, P., \& Riemer, H. A. (1998). Measurement of leadership in sport. InJ.L.Duda (Ed.), Advances in sport and exercise psychology measurement (pp 227-253) Morgantown, WV: Fitness Information Technologies.

Cooper, R., \& Payne, R. (1972). Personality orientations and performance in soccer teams. British Journal of Social and Clinical Psychology, 2, 2-9. https://doi.org/10.1111/j.2044-8260.1972.tb00772.x

Doğan, E., Yılmaz, A. K., Kabadayı, M., \& Mayda, M. H. (2018). Spor Bilimleri Öğrencileri İle Farklı Fakültelerde Okuyan Öğrencilerin Sosyalleşme Ve Mutluluk Düzeylerinin İncelenmesi. Kafkas Üniversitesi Sosyal Bilimler Enstitüsü Dergisi, 22, 403-411.

Donuk, B. (2006). Türkiye Profesyonel Futbol Ligleri Antrenörlerinin Liderlik Tarzlarının İncelenmesi ve Bir Model.

Gardner, D. E., Shields, D. L., Bredemeier, B. J., \& Bostrom (1996). The relationship between perceived coaching behaviors and team cohesion baseball and soflball players. The Sport Psychologist, 10, 367-381. https://doi.org/10.1123/tsp.10.4.367

Garland, D. J., \& Barry, J. R. (1988). The effects of personality and perceived leader behavior on performance in collegiate football .Psychological Record, 38, 237-247. https://doi.org/10.1007/BF03395019

Goldberg, A. S. (1998). Sports sump busting. IIIinois: Human Kinetics.

Gordon, S. (1998). Decision styles and coaching effectiveness in university soccer. Canadian Journal of Sport Science, $13(1), 36-55$.

Horne, T., \& Carron, A. V. (1985). Compatibility in coach-athlete relationship. Journal of Sport Psychology, 7, $137-149$. https://doi.org/10.1123/jsp.7.2.137

Kabaday1, M., Eski, T., Bayram, L., Y1lmaz, A. K., \& Mayda, M. H. (2017). Analysis of the factors which influence participation of university students in recreational activities. European Journal of Education Studies.

Kaya, K. Y. (1996). Eğitim Yönetimi. Bilim. Kitap ve Kırtasiye Ltd Şti. Ankara.

Keskin, D. Ö. Y., Bayram, L., Derebaşı, D. G., Bostanc1, Ö., \& Kabadayı, M. (2016). Üniversite Öğrencilerinin Kullandıkları Karar Verme Stratejilerinin Bazı Demografik Değişkenlere Göre İncelenmesi. Gaziantep Üniversitesi Spor Bilimleri Dergisi, 1(2), 1-12.

Konter, E. (1996). Spor psikolojisi ve futbol. Izmir: Saray Medikal Yayincilik.

Konter, E. (1997). Futbol'da süratin teori ve pratigi. Ankara: Bagirgan Yayimevi. 
Konter, E. (2004). Profesyonel Futbolcuların Kaptan Olup-Olmamalarına Göre Psikolojik Becerilerinin Araştırılması. Gazi Beden Eğitimi Ve Spor Bilimleri Dergisi, 9(1), 25-34.

Konter. E. (2005). Profesyonel futbolcuların yaş gruplarına göre psikolojik becerilerinin araştırılması. Gazi Beden Eğitimi ve Spor Bilimleri Dergisi, 5(1), 17-24.

Lee, M. J, Coburn, T., \& Partridge, R. (1983). The influence of team structure in determining leadership function in association football. Journal of Sport Behavior, 6, 59-66.

Leonard II, W. M. (1987). Stacking in college basketball: A neglected analysis. Sociology of Sport Journal. 4. 403-409. https://doi.org/10.1123/ssj.4.4.403

Maby, R. K. (1997). The relationship between perceived coaching behaviors and group cohesion in professional football. Nova Southeasthern University. Dissertation Abstracts International Section B. The Sciences and Engineering, 57(9-B). 5902.

Ödemiş, M., \& Karagün, E. (2016). Leadership behaviours that dance athletes perceive and prefer. Journal of Human Sciences, 13(3). 5201-5213. https://doi.org/10.14687/jhs.v13i3.4030

Pargman, D. (1998), Understanding Sport Behavior. New Jersey: Prentice Hall, 48, 279, 287, 293-94, $296-97$.

Prapavessis, H., \& Gordon, S. (1991). Coach/player relationships in tennis. Canadian.

Renklikurt, T. (1991). Futbol kondisyon el kitabi. Istanbul: Türkiye Futbol Federasyonu Egitim Yayinlari-8.

Riemer, H. A., \& Chelladurai, P. (1995). Leadership and satisfaction in athletics. Journal of Sport and Exercise Psychology, 17, 276-293. https://doi.org/10.1123/jsep.17.3.276

Robinson, T. T., \& Carron, A. V. (1982). Personal and situational factors associated with dropping out versus maintaining participation in competitive sport. Journal of Sport Psychology, 4, 364-378. https://doi.org/10.1123/jsp.4.4.364

Summers, R. J., \& Russel, J. (1991). Association between athletes' perception of their abilities on the influence of coach technicalinstruction. Journal of Sport Behavior. 14(1), 30-40.

Türksoy, A. (2006). Futbolda Sporcu Tatmini İle Antrenörlerden Beklenilen ve Gerçekleşen Liderlik Davranışlarının Yaklaşım. İstanbul. Marmara Üniversitesi Sağllk Bilimleri Enstitüsü. Doktora Tezi, 25-29.

Yilmaz, A. K., Kabadayi, M., Mayda, M. H., Birinci, M. C., \& Özdal, M. (2017). The effects of isokinetic knee strength on the promptness of soccer players. European Journal of Physical Education and Sport Science.

Yukelson, D., Weinberg, R., Richardson, P., \& Jackson, A. (1983). Interpersonal attraction and leadership within collegiate sport teams. Journal of Sport Behavior, 6(1), 28.

\section{Copyrights}

Copyright for this article is retained by the author(s), with first publication rights granted to the journal.

This is an open-access article distributed under the terms and conditions of the Creative Commons Attribution license which permits unrestricted use, distribution, and reproduction in any medium, provided the original work is properly cited. 